\title{
HUMAN HEALTH IMPLICATIONS OF OUTDOOR AIR POLLUTION BY POLYCYCLIC AROMATIC HYDROCARBONS IN ALEXANDRIA CITY, EGYPT
}

\author{
Ashraf A. Zahran ${ }^{1 *}$, Alaa R. Mostafa ${ }^{2}$, Nermine M. Foda ${ }^{3}$, Mohamed Y. Omar ${ }^{4}$ and Maram O. Nadry ${ }^{2}$ \\ ${ }^{1}$ Department of Natural Resources and Planning to Development, Environmental Studies and Research Institute, \\ University of El Sadat City, Sadat City, Egypt \\ ${ }^{2}$ Faculty of Science, Alexandria University, Egypt \\ ${ }^{3}$ Faculty of Medicine, Alexandria University, Egypt \\ ${ }^{4}$ Arab Academy for Science, Technology and Maritime Transport, Egypt
}

https://doi.org/10.35410/IJAEB.2020.5510

\begin{abstract}
In this study, two receptor models [factor analysis/multiple linear regression (FA/MLR) and positive matrix factorization (PMF)] were applied seasonally to investigate the source apportionment of Polycyclic aromatic hydrocarbons (PAHs) in the atmospheric environment of Alexandria, and a lifetime cancer risk was assessed. $\sum 35$ (particle) PAHs concentrations varied from $343.68 \mathrm{ng} / \mathrm{m} 3$ to $7847.9 \mathrm{ng} / \mathrm{m} 3$ in summer, from $532.68 \mathrm{ng} / \mathrm{m} 3$ to $1942.4 \mathrm{ng} / \mathrm{m} 3$ in Autumn, from $317.17 \mathrm{ng} / \mathrm{m} 3$ to $4433.25 \mathrm{ng} / \mathrm{m} 3$ in Winter and from $551.7 \mathrm{ng} / \mathrm{m} 3$ to $2987 \mathrm{ng} / \mathrm{m} 3$ in spring. PAH concentrations at the industrial sites were significantly higher than at the traffic and residential sites during the winter season $(\mathrm{p}<0.001)$. Summer PAH concentrations were significantly higher than the winter season at the traffic sites $(\mathrm{p}=0.027)$. Results obtained from the two receptor models were comparable. Vehicle emissions and combustion are the main sources of pollution. Overall, PMF afforded better source identification than did FA/MLR. The lifetime cancer risk assessment showed that incremental lifetime cancer risks (ILCRs) were greater than the acceptable level of 10_6 through dermal and ingestion routes at all the investigated sites and through the inhalation route at the industrial and traffic sites only. So, the government should focus its attention and regulations on corrective actions to protect the public against the hazards of air pollution.
\end{abstract}

Keywords: Outdoor air pollution; Polycyclic aromatic hydrocarbons (PAHs); Factor Analysis/Multiple Linear Regression, Positive Matrix Factorization, Health risk assessment.

\section{INTRODUCTION}

PAHs are organic compounds made up of two or more fused organic rings. These organic rings are generated through the incomplete combustion of fossil fuels along with organic material like waste incineration, coal and petroleum product combustion, power generation plants, tobacco smoking and food cooking (The agency for toxic substances and disease registry (ATSDR), 1995; Bartle, 1991). People are mainly exposed to PAHs via inhalation of smoke (tobacco, wood, coal, etc.) and other air pollutants, and by ingesting food containing PAHs. Workers at workplaces and other facilities that use or produce petroleum or coal or burn organic material may be exposed to PAHs (US Department of Health and Human Services, 2019). In addition, 
Vol. 5, No. 03; 2020

ISSN: $2456-8643$

these fused aromatic rings are highly persistent and toxic. PAHs are pollutants that spread everywhere and are considered hazardous due to their carcinogenic and mutagenic potential. Hence, they are widely studied in different biological and environmental milieus (Ravindra et al., 2006; Krauss et al., 2005; Baumard et al., 1998). PAHs negative impact is not only restricted to flora and fauna, but also extends to humans and, as a result, they are deemed significant pollutants by international environmental protection agencies (Kennish, 1992; Oliva et al., 2010). The united states environmental protection agency (US EPA) has included sixteen PAHs in its priority control list and indicated that the following seven PAH compounds: benz(a)anthracene, benzo(a)pyrene, benzo(b)fluoranthene, benzo(k)fluoranthene, chrysene, dibenz(ah)anthracene, and indeno(1,2,3-cd) pyrene as probable human carcinogens (US EPA), 2008).

Basic science and public health research have recently indicated a close relation between exposure to PAH and cardiovascular disease. Injections of PAHs in several animal species greatly intensifies aortic plaque volumes depending on the injected dose. In addition, permanent exposure to PAH leads to the aggravation of the inflammatory cells in atherosclerotic plaques (Albert et al., 1977; Curfs et al., 2005; Penn and Snyder, 1988).

Egypt's growing population, rapid urbanization, industrial expansion, as well as excessive usage of fossil fuels in automobiles, trucks and public transportation (Egyptian Environmental Affairs Agency (EEAA), 2007) has led to release of huge amounts of pollutants in the atmosphere, which has aggravated concern about the potential risk of these pollutants to public health. Given this fact, available data on the level of PAHs in Egypt's atmospheric environment are rare due to several application hindrances. However, there are some studies discussing the levels of aliphatic and aromatic hydrocarbons in particulate fallout (Aboul-Kassim and Simoneit, 1995; Barakat, 2002). Another study focused on PAHs concentrations and selected nitrated derivatives in the particulates totally suspended and collected from Greater Cairo, Egypt (Nassar et al., 2011), Yet, there is a gap in the research as regards the emission sources of PAHs in any of the major urban cities of Egypt.

This study has three main objectives: first, to decide on the level and distribution of PAHs pollution, secondly, to focus on the sources emitting PAHs and the FA/MLR and PMF receptor models, and, final, to evaluate the hazardous health effects of PAHs in the City of Alexandria.

\section{MATERIALS AND METHODS}

\section{Sampling area description}

The city of Alexandria is the second largest city of Egypt with a total surface area of $2300 \mathrm{~km} 2$, extending for nearly $90 \mathrm{~km}$ along the coast of the Mediterranean Sea to the northwest of the Nile Delta and a population of 4.1 million. It is the biggest seaport of Egypt, as it serves about $80 \%$ of Egypt's import-export trade, and an industrial hub since $40 \%$ of Egypt's industrial activities and $60 \%$ of petroleum activities are located in it (EEAA, 2007). Moreover, being a coastal city, it is one of the well-recognized tourist and recreational resorts visited annually by almost 2 million tourists. Although, the climate of Alexandria is arid, the north wind that blows and prevails across the Mediterranean makes the city climate different from the desert hinterland. Alexandria has a mild Mediterranean weather with rainy winters and hot and humid summers. The coolest 
months are January and February with daily maximum temperatures ranging from $12^{\circ} \mathrm{C}$ to $18^{\circ} \mathrm{C}$ and minimum temperatures about $5^{\circ} \mathrm{C}$. There can also be violent storms, heavy rains and sometimes hail. On the other hand, July and August are the hottest and driest months in summer, with a daily temperature that rarely exceeds $30^{\circ} \mathrm{C}$ (EEAA, 2007).

As for the Alexandrian roads, whether paved or unpaved, they are $5310 \mathrm{~km}$ in length and the number of licensed vehicles of any type is 540000 . This makes the number of vehicles per kilometer 95. Of the total number of licensed cars, private cars amount to $68 \%$, then come the light and medium duty trucks $15 \%$, followed by taxis $5 \%$, private and public transportation buses $2 \%$, heavy-duty truck $2 \%$, and finally are the vehicles, of various types, owned by the governmental sector $3 \%$. Given the cheap price of diesel in comparison to gasoline, the majority of the buses, light, medium and heavy-duty buses are powered by diesel (Central Agency for Public Mobilization and Statistics (CAMPAS), 2012).

\section{Particulate sampling and preparation}

A stratified sampling strategy was used to assess the PAH pollution in Alexandria while collecting a sample of 48 atmospheric particulate samples during the period from March 2012 to February 2013, covering the four seasons. Samples were taken from six locations in the city as follows: Smouha, El Asafra, Ras El-Teen, Wadi El Qamar, Misr Station, and Abo Qir Street (Fig. 1). Taking into account the land use pattern as well as the demographic characteristics of Alexandria, the above-mentioned sites were selected because they include a variety of activities. The traffic-residential mixed pattern reflects that the sample was taken from a main road full of high traffic density and surrounded by residential blocks. On the other hand, a residential-traffic shows that the sample was taken from a side road that has a big density of residential blocks, but with lighter traffic. To make it more obvious, the selected areas were classified according to the major activity dominating the area such as traffic, residential and industrial sites. A Staplex highvolume air sampler (model TIAF-2) with a glass fiber filter (GFF, $10 \mathrm{~cm}$ diameter) was used for active sampling and collecting the particle-bound compounds. A total of $48 \mathrm{GFF}$ were collected from the six locations for a period of 2-3 days and analyzed in all seasons to cover the factor of sampling dates, whereas the meteorological parameters of ambient temperature and wind speed were measured during the sampling time (Table 1).

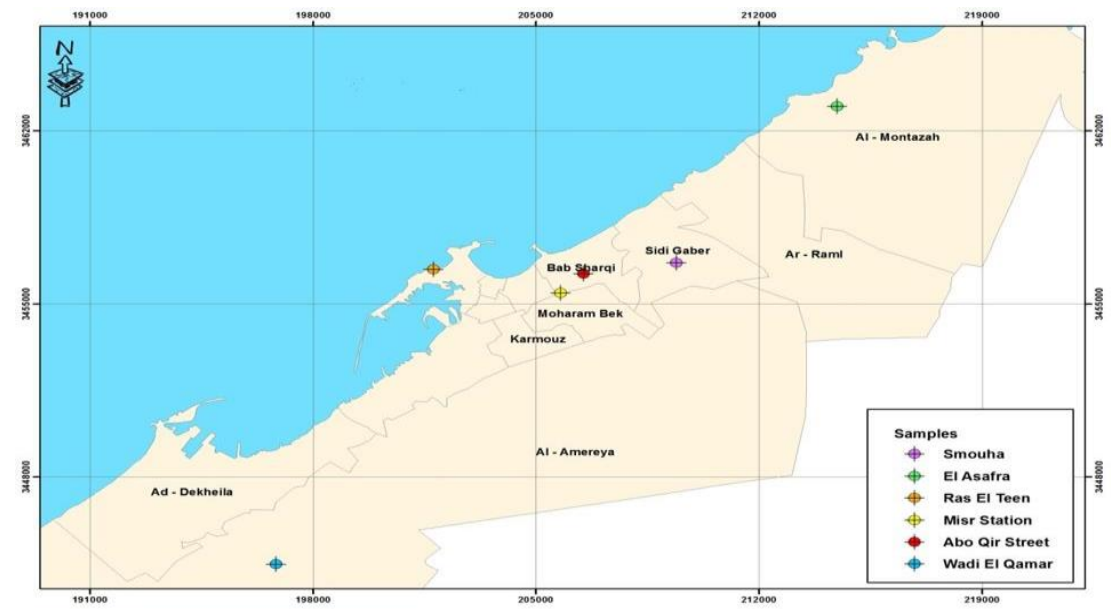




\section{International Journal of Agriculture, Environment and Bioresearch}

Vol. 5, No. 03; 2020

ISSN: $2456-8643$

Fig. 1: Study area with sampling stations

Table 1: Meteorological information of the sampling locations in Alexandria

\begin{tabular}{|c|c|c|c|c|c|c|c|c|c|}
\hline \multirow{2}{*}{ Station } & \multirow{2}{*}{ Lat. $\mathrm{N}$} & \multirow{2}{*}{ Long. E } & \multirow{2}{*}{$\begin{array}{c}\text { Expected } \\
\text { emission } \\
\text { source }^{\mathrm{a}} \\
\end{array}$} & \multicolumn{4}{|c|}{ Sampling dates } & \multirow{2}{*}{$\begin{array}{l}\text { Average } \\
\text { day/night } \\
\text { Temp. }{ }^{0} \mathrm{C}^{\mathrm{b}} \\
\end{array}$} & \multirow{2}{*}{$\begin{array}{l}\text { Wind } \\
\text { speed } \\
(\mathrm{m} / \mathrm{s})^{\mathrm{c}}\end{array}$} \\
\hline & & & & Spring & Summer & Autumn & Winter & & \\
\hline Smouha & $31^{\circ} 12^{\prime} 27.53^{\prime \prime}$ & $29^{\circ} 56^{\prime} 25.74^{\prime \prime}$ & $\begin{array}{c}\text { Residential } \\
\text { Traffic }\end{array}$ & $21-22 / 3 / 12$ & $5-6 / 7 / 12$ & $11-13 / 10 / 12$ & $8-10 / 1 / 13$ & $23.5 / 16$ & $(2.52-4.55)$ \\
\hline $\begin{array}{c}\text { El- } \\
\text { Asafra }\end{array}$ & $31^{\circ} 16^{\prime} 6.98^{\prime \prime}$ & $30^{\circ} 0^{\prime} 29.56^{\prime \prime}$ & Residential & $24-25 / 3 / 12$ & $9-10 / 7 / 12$ & $16-17 / 10 / 12$ & $15-17 / 1 / 13$ & $24.3 / 17.4$ & $(2.36-4.55)$ \\
\hline $\begin{array}{c}\text { Wadi } \\
\text { El- } \\
\text { Qamar }\end{array}$ & $31^{\circ} 8^{\prime} 20.99^{\prime \prime}$ & $29^{\circ} 50^{\prime} 17.80^{\prime \prime}$ & $\begin{array}{c}\text { Industrial } \\
\text { Traffic } \\
\text { Residential }\end{array}$ & $27-28 / 3 / 12$ & $13-15 / 7 / 12$ & $18-20 / 10 / 12$ & $20-22 / 1 / 13$ & $29.9 / 18.4$ & $(2.01-4.66)$ \\
\hline $\begin{array}{c}\text { Ras } \\
\text { El-Teen }\end{array}$ & $31^{\circ} 12^{\prime} 6.34^{\prime \prime}$ & $29^{\circ} 52^{\prime} 29.23^{\prime \prime}$ & Residential & $31 / 3-1 / 4 / 12$ & $24-25 / 7 / 12$ & $25-27 / 10 / 12$ & $2-3 / 2 / 13$ & $25.5 / 16.4$ & $(2.15-4.87)$ \\
\hline $\begin{array}{l}\text { Abo Qir } \\
\text { Station }\end{array}$ & $31^{\circ} 12^{\prime} 11.86^{\prime \prime}$ & $29^{\circ} 55^{\prime} 15.17^{\prime \prime}$ & Traffic & $2-3 / 4 / 12$ & $11-12 / 8 / 12$ & $8-10 / 11 / 12$ & $12-14 / 2 / 13$ & $29.8 / 18.4$ & $(2.45-4.55)$ \\
\hline $\begin{array}{c}\text { Misr } \\
\text { Station }\end{array}$ & $31^{\circ} 11^{\prime} 28.89^{\prime \prime}$ & $29^{\circ} 54^{\prime} 15.02^{\prime \prime}$ & Traffic & $4-5 / 4 / 12$ & $15-17 / 8 / 12$ & $22-24 / 11 / 12$ & $23-25 / 2 / 13$ & $27.5 / 17.4$ & $(2.22-4.63)$ \\
\hline
\end{tabular}

a) expected were ordered based on their significance

b) average temperature during the sampling period in the four seasons

c) average wind speed during the sampling period in the four seasons

\section{Sample extraction, clean up and analysis}

Before the air sample collection process, cleaning procedures were done to filters and all the solvents and reagents applied in the study were of chromatographic grade. Before extracting the samples, surrogates $\mathrm{d} 8$-Naphthalene, d10-Acenaphthene, d10-Phenanthrene, d12-Chrysene and d12-Perylene were added to them. Then the samples were extracted and analyzed by the Geochemical and Environmental Research Group (GERG), Texas A\&M University, USA and the alumina/silica gel (80-100 mesh) column chromatography was used to fraction the concentrated extracts. Target analyses were eluted from the column with $200 \mathrm{ml}$ of 1:1 pentanedichloromethane (aromatic/PCB/pesticide fractions). Then Kuderna-Danish concentrated tubes heated in a water bath at $60^{\circ} \mathrm{C}$ were used to concentrate the fraction to $1 \mathrm{ml}$. PAHs were analyzed with a Hewlett Packard 5890 gas chromatograph equipped with a 5970B mass selective detector using a $3 \mathrm{~m} \times 0.25 \mathrm{~mm}$ (i.d.) DB-5 fused silica capillary column (J \& W Scientific) and operating in the selected ion mentoring (SIM) mode.

Along with the analytical procedure of the set of samples a procedural blank, matrix spike, and a duplicate sample were carried out in a manner similar to the samples. The procedural blank concentrations were only 3 and the detection method of the method ranged from 0.48 (dibenzothiophene) to $8.21 \mathrm{ng} / \mathrm{g}(\mathrm{Cl}$-fluoranthene). As for the recoveries in matrix spikes, they 
were $75-120 \%$ and the relative percent difference (RPD) of duplicate sample was less than $25 \%$. For further quality assurance checks, certified standard reference materials (NIST SRM 1941, New York/New Jersey Waterway Sediment) were analyzed. It becomes clear that the PAHs recoveries in the certified marine sediment calibration solution. Throughout each analytical sequence, the Gas Chromatography-Mass spectrometry (GC/MS) calibration was SRM were nearly $83 \%$ of the certified concentration. Besides, in order to confirm the GC/MS/SIM system performance and calibration, analysis of a laboratory reference sample (diluted oil sample) was done with each batch of samples and the instrumental calibration were checked through injecting the continuing verified and the calibration check was maintained within $\pm 15 \%$ for all analytes in question. The extracts were checked for $35 \mathrm{PAHs}$ including the following: Acenaphthylene (ANL), Acenaphthene (AN), Naphthalene (Nap), Biphenyl (Biph), Fluorene (Flu), Phenanthrene (Phe), Anthracene (Ant), Fluoranthene (Fla), Pyrene (Pyr), Dibenzothiophene (Diben), Benzo[a]anthracene $(\mathrm{BaA})$, chrysene $(\mathrm{Chr})$, benzo[b]fluoranthene $(\mathrm{BbF})$, benzo[k]fluoranthene $(\mathrm{BkF})$, benzo[a]pyrene (BaP), Benzo[e]pyrene (BeP), Perylene (Per), Indeno[1,2,3-c,d]pyrene (IP), dibenzo [a,h] anthracene (DBahA), 2-Methylnaphthalene, 1-Methylnaphthalene, 2,6Dimethylnaphthalene, 1,6,7-Trimethylnaphthalene, 1-Methylphenanthrene, and Benzo[g,h,i] perylene $(\mathrm{BgP})$.

\section{Quality assurance and quality control (QA/QC)}

Wade et al. (1988) discussed the procedures of quality assurance and quality control (QA \& QC) applied to GC/MS analyses. The analysis adopted the complete data quality objectives for instrument calibration, analyte recoveries matrix spike, standard reference material (accuracy) analysis and duplicate (precision) analysis. The surrogate recovery of quality control acceptance ranges between $40 \%$ and $120 \%$. The comparison between the retention times of the target compounds in the calibration standards and the sample set to indicate the GC/SM system performance and calibration formed the basis for identification of compounds.

\section{Source identification methods}

Sources of PAHs have been identified by various methods including the diagnostic ratio (Tobiszewski and Namiesnik, 2012) and receptor- oriented models (Larsen and Baker, 2003; Lestari and Mauliadi, 2009; Zhang et al., 2012). To measure the sources of PAHs in the atmospheric samples in the current study diagnostic ratios, FA/MLR and PMF, the representative receptor models were applied. In order to specify the potential PAHs sources its diagnostic sources like ratios of Benzo (g,h,i) perylene BaP/BghiP, IcdP/ (IcdP + BghiP) and Ant/ (Phe + Ant), Flu/ (Flu + Pyr) are used (Yunker et al., 2002). Despite the fact that using diagnostic ratios was not recommended by several researchers for their well-recognized uncertainties, they were used in the current study as a means to investigate the sources (Katsoyiannis et al., 2007, 2011; Galerneau, 2008; Katsoyiannis and Breivik, 2014). Paatero and Tapper (1994) set up PMF model and made use of the non-negativity constraints to get physically realistic meanings. Moreover, the PMF was used to indicate the various sources of PAHs (Zhang et al., 2012; Wang et al., 2013).

In PMF model a matrix $X$ of data of dimension $n$ rows and $m$ columns, where $n$ and $m$ are the number of samples and the number of species is categorized in two matrixes $G(n \times p)$ and $F(p \times$ $m$ ), in addition to the residual matrix $E$, where $p$ is the number of factors involved. 
Vol. 5, No. 03; 2020

ISSN: $2456-8643$

$X=G F+E$

The product of $G$ and $F$ explains the systematic variations in $X$. The residuals, $\mathrm{E}_{\mathrm{ij}}$ can

$$
E i j=X i j-\sum_{n=1}^{p} \quad \text { Gin } . F n j
$$

The object function $Q$ that has to be minimized is defined as:

$Q(E)=\sum_{i=1}^{m} \quad \sum_{j=1}^{n} \quad\left(\frac{E i j}{S i j}\right) 2$

EPA PMF (V5.0) resolved the data whose input file is made up of receptor concentration (C) and uncertainty $(\mathrm{U})$ matrices. The $\mathrm{U}$ if each variable is measured using $\mathrm{C}$ and the method detection limit (MDL). It was concluded that when $\mathrm{C}$ is above the MDL, the $\mathrm{U}$ is used to $(0.1 \mathrm{C}+\mathrm{MDL} / 3)$, and if $\mathrm{MDL} / 2$ substituted $\mathrm{C}, \mathrm{U}$ is supposed to (0.2C+MDL/3) (Tauler et al., 2009; Jang et al., 2013).

\section{Risk Assessment}

The incremental lifetime cancer risk (ILCR) was calculate, following the US EPA standard models (US EPA, 1991; Chen and Liao, 2006; Peng et al., 2011; Wang et al., 2011), to quantify the environmental PAHs exposure risk. After exposure of various areas in Alexandria to PAHs, the ILCRs was calculated given ingestion, dermal contact and inhalation as follows:

ILCRs Ingestion $=\frac{\operatorname{css}\left(\operatorname{csf} * \sqrt{\left.\left(\frac{B W}{70}\right)\right) * \text { IRingestion*EF } * E D}\right.}{B W * A T * 10}$

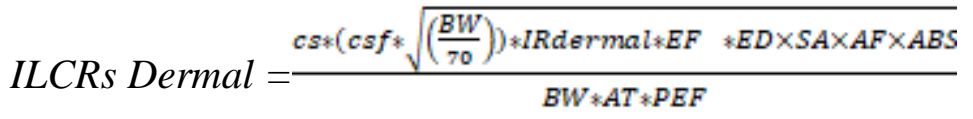

ILRCS Inhalation $=\frac{\operatorname{cs} *\left(\operatorname{csf} * \sqrt{\left.\left(\frac{(W W}{70}\right)\right) * I R i n h a l a t i o n * E F * E D}\right.}{B W * A T * P E F}$

In the above equation, the $C S$ is the total of the PAH levels that are converted due to toxic equivalents of $\mathrm{BaP}$ by using the toxic equivalency factor (TEF). CSF is carcinogenic slope factor $\left(\mathrm{mg} \mathrm{kg}^{-1} \mathrm{day}^{-1}\right)^{-1}$, BW is body weight $(\mathrm{kg})$, AT is the average life span (years), EF is the exposure frequency (day year-1 ${ }^{-1}$, ED is the exposure duration (years), IR Inhalation is the inhalation rate $\left(\mathrm{m}^{3}\right.$ day $\left.^{-1}\right)$, IR Ingestion is the intake rate $\left(\mathrm{mg} \mathrm{day}^{-1}\right), \mathrm{SA}$ is the dermal surface exposure $\left(\mathrm{cm}^{2}\right)$, $\mathrm{AF}$ is the dermal adherence factor $\left(\mathrm{mg} \mathrm{cm}^{-2} \mathrm{~h}^{-1}\right)$, ABS is the dermal adsorption fraction, and PEF is the particle emission factor $\left(\mathrm{m}^{3} \mathrm{~kg}^{-1}\right)$. PEF is particle emission factor $\left(\mathrm{m}^{3} \mathrm{~kg}^{-1}\right)$; CSF ingestion, CSF Dermal and CSF Inhalation of BaP were addressed as 7.3,25, and $3.85\left(\mathrm{mg} \mathrm{kg}^{-1} \text { day }^{-1}\right)^{-1}$, respectively, determined by the cancer-causing ability of BaP (Peng et al., 2011). The Risk Assessment Guidance of US EPA and its relevant publications formed the basis of all the parameters used in the above models for adults ranging from 18 to 60 years old (US EPA, 1991; Wang et al., 2011). 
Vol. 5, No. 03; 2020

ISSN: $2456-8643$

\section{RESULTS AND DISCUSSION} Levels and distribution of PAHs

The descriptive statistical summary of PAHs concentrations resulted in the particle phase throughout the four seasons is illustrated in Table (2). In summer, PAHs ranged from 343.68 $\mathrm{ng} / \mathrm{m}^{3}$ to $7847.9 \mathrm{ng} / \mathrm{m}^{3}$, in autumn from $532.68 \mathrm{ng} / \mathrm{m}^{3}$ to $1942.4 \mathrm{ng} / \mathrm{m}^{3}$, in winter from 317.17 $\mathrm{ng} / \mathrm{m}^{3}$ to $4433.25 \mathrm{ng} / \mathrm{m}^{3}$, and in spring from $551.7 \mathrm{ng} / \mathrm{m}^{3}$ to $2987 \mathrm{ng} / \mathrm{m}^{3}$. When compared with relevant data taken from different urban sites, it becomes clear that PAHs concentrations obtained in this study are higher than those observed in the urban areas of Tuscany, Italy (0.92$13 \mathrm{ng} / \mathrm{m}^{3}$, Martellini et al., 2012), in Venice, Italy ( $\sum 15$ PAHs ranges from 1.5 to $5.2 \mathrm{ng} / \mathrm{m}^{3}$, Gregoris et al., 2014), in Lisbon, Portugal (average of $70 \mathrm{ng} / \mathrm{m}^{3}$, Slezakova et al., 2013), in Beijing-Tianjin, China $\left(\sum 15 \mathrm{PAHs}=50.5 \pm 15.7 \mathrm{ng} / \mathrm{m}^{3}\right.$. Wang et al., 2011), in Harbin, China $\left(\sum 16\right.$ PAHs $=100 \pm 94.0 \mathrm{ng} / \mathrm{m}^{3}$, Ma et al., 2010), in Guangzhou, China $\left(\sum 16 \mathrm{PAHs}=340 \pm 140\right.$ $\mathrm{ng} / \mathrm{m}^{3}$, Li et al., 2006), Chicago, USA ( $\sum 26$ PAHs $=167 \pm 164 \mathrm{ng} / \mathrm{m}^{3}$, Simcik et al., 1999), in Seoul, Korea $\left(\sum 16\right.$ PAHs $=89.3 \pm 74.3 \mathrm{ng} / \mathrm{m}^{3}$, Park et al., 2002), in Athens, Greece ( $\sum 14$ PAHs $=28.4 \pm 1.63 \mathrm{ng} / \mathrm{m}^{3}$, Vasilakos et al., 2007), in Bursa, Turkey during the non-heating season $\left(\sum 14 \mathrm{PAHs}=300 \pm 420 \mathrm{ng} / \mathrm{m}^{3}\right.$, Esen et al., 2008), in Kocaeli, an industrial city in Turkey (423.9 $\mathrm{ng} / \mathrm{m}^{3}$ "winter" and $108.3 \mathrm{ng} / \mathrm{m}^{3}$ "summer", Gaga et al., 2012), and in Flanders, Belgium $\left(\sum 16\right.$ PAHs: $57.8 \pm 43.0 \mathrm{ng} / \mathrm{m}^{3}$, Ravindra et al., 2006), but lower than those observed in Giza, Egypt $\left(\sum 14\right.$ PAHs $=4,342 \mathrm{ng} / \mathrm{m}^{3}$, Hassan and Khoder, 2012).

Table 8: Concentration levels of PAHs in the atmosphere of different countries

\begin{tabular}{|c|c|c|c|c|}
\hline Country & Site & No of PAHs & Conc. Of PAHs & Reference \\
\hline \multirow{2}{*}{ Italy } & Tuscany & $\sum 15$ & $0.92-13 \mathrm{ng} \mathrm{m}^{-3}$ & Martellini et al., 2012 \\
\hline & Venice & $\sum 15$ & 1.5 to $5.2 \mathrm{ng} / \mathrm{m}^{3}$ & Gregoris et al., 2014 \\
\hline Portugal & Lisbon & $\sum 16$ & average of $70 \mathrm{ng} \mathrm{m}^{-3}$ & Slezakova et al., 2013 \\
\hline \multirow{3}{*}{ China } & Beijing-Tianjin & $\sum 15$ & $50.5 \pm 15.7 \mathrm{ng} / \mathrm{m}^{3}$ & Wang et al., 2011 \\
\hline & Harbin & $\sum 16$ & $100 \pm 94.0 \mathrm{ng} \mathrm{m}^{-3}$ & Ma et al., 2010 \\
\hline & Guangzhou & $\sum 16$ & $340 \pm 140 \mathrm{ng} \mathrm{m}^{3}$ & Li et al., 2006 \\
\hline USA & Chicago & $\sum 26$ & $167 \pm 164 \mathrm{ng} \mathrm{m}^{3}{ }^{3}$ & Simcik et al., 1999 \\
\hline Korea & Seoul & $\sum 16$ & $89.3 \pm 74.3 \mathrm{ng} \mathrm{m}^{3}$ & Park et al., 2002 \\
\hline Greece & Athens & $\sum 14$ & $28.4 \pm 1.63 \mathrm{ng} \mathrm{m}^{-3}$ & Vasilakos et al., 2007 \\
\hline \multirow[b]{2}{*}{ Turkey } & Bursa & $\sum 14$ & $300 \pm 420 \mathrm{ng} \mathrm{m}^{-3}$ & Esen et al., 2008 \\
\hline & Kocaeli & $\sum 13$ & $\begin{array}{c}423.9 \text { ng/m } / \mathrm{m}^{3} \text { "winter" } \\
108.3 \mathrm{ng} / \mathrm{m}^{3} \text { "summer" }\end{array}$ & Gaga et al., 2012 \\
\hline Belgium & Flanders & $\sum 16$ & $57.8 \pm 43.0 \mathrm{ng} \mathrm{m}^{-3}$ & Ravindra et al., 2006 \\
\hline \multirow{3}{*}{ Egypt } & Giza & $\sum 14$ & $4,342 \mathrm{ng} \mathrm{m}^{-3}$ & Hassan and Khoder, 2012 \\
\hline & Alexandria & $\sum 16$ & $740 \pm 365 \mathrm{ng} \mathrm{m}^{-3}$ & Khairy et al., 2013 \\
\hline & Alexandria & $\sum 16$ & $\begin{array}{c}847 \pm 103.2 \mathrm{ng} \mathrm{m}^{-3} \text { (Spring) } \\
958 \pm 245.3 \mathrm{ng} \mathrm{m}^{-3} \text { (Summer) }\end{array}$ & The current study \\
\hline
\end{tabular}


Vol. 5, No. 03; 2020

ISSN: $2456-8643$

$725 \pm 123.8 \mathrm{ng} \mathrm{m}^{-3}$ (Autumn)

$649 \pm 212.8 \mathrm{ng} \mathrm{m}^{-3}$ (Winter)

As for the PAHs concentrations in the urban areas of Alexandria, they were as follows: they ranged between 68866 and $33952 \mathrm{ng} / \mathrm{m} 3$ with average concentration of $51409 \pm 431 \mathrm{ng} / \mathrm{m} 3$ in Wadi El Qamar, 58587 and $11903 \mathrm{ng} / \mathrm{m} 3$ with average concentration of $13458.8 \pm 394 \mathrm{ng} / \mathrm{m} 3$ in Misr Station, 48354 and $37486.8 \mathrm{ng} / \mathrm{m} 3$ with average concentration of $42920 \pm 252 \mathrm{ng} / \mathrm{m} 3 \mathrm{in}$ Smouha, 32223 and $15321 \mathrm{ng} / \mathrm{m} 3$ with average concentration of $23772 \pm 170 \mathrm{ng} / \mathrm{m} 3$ in Abo Qir street, 23008 and $19310 \mathrm{ng} / \mathrm{m} 3$ with average concentration of $21159 \pm 619 \mathrm{ng} / \mathrm{m} 3$, and, finally, in Ras El Teen between 8738 and $4620 \mathrm{ng} / \mathrm{m} 3$ with average concentration of $6649 \pm 74 \mathrm{ng} / \mathrm{m} 3$.

With regards to seasons, PAHs concentrations ranged between $7383.018 \mathrm{ng} / \mathrm{m} 3$ and 123910.8 $\mathrm{ng} / \mathrm{m} 3$ in summer, $184.99 \mathrm{ng} / \mathrm{m} 3$ and $33365.39 \mathrm{ng} / \mathrm{m} 3$ in autumn, $153.48 \mathrm{ng} / \mathrm{m} 3$ and 82205.42 $\mathrm{ng} / \mathrm{m} 3$ in winter and $5615.315 \mathrm{ng} / \mathrm{m} 3$ and $35982.8 \mathrm{ng} / \mathrm{m} 3$ in spring, indicating average concentrations of $34035.6 \pm 496.7,17999.6 \pm 145.6,24231.4 \pm 204.5$, and $18446.9 \pm 899.2 \mathrm{ng} / \mathrm{m} 3$, respectively. Thus, during the four seasons, PAHs concentrations were considerably higher at the industrial sites compared to the traffic and the residential sites (One-way ANOVA, with Chisquare $=142.657$ with 5 degrees of freedom $(P=<0.001)($ Fig. 2$)$.

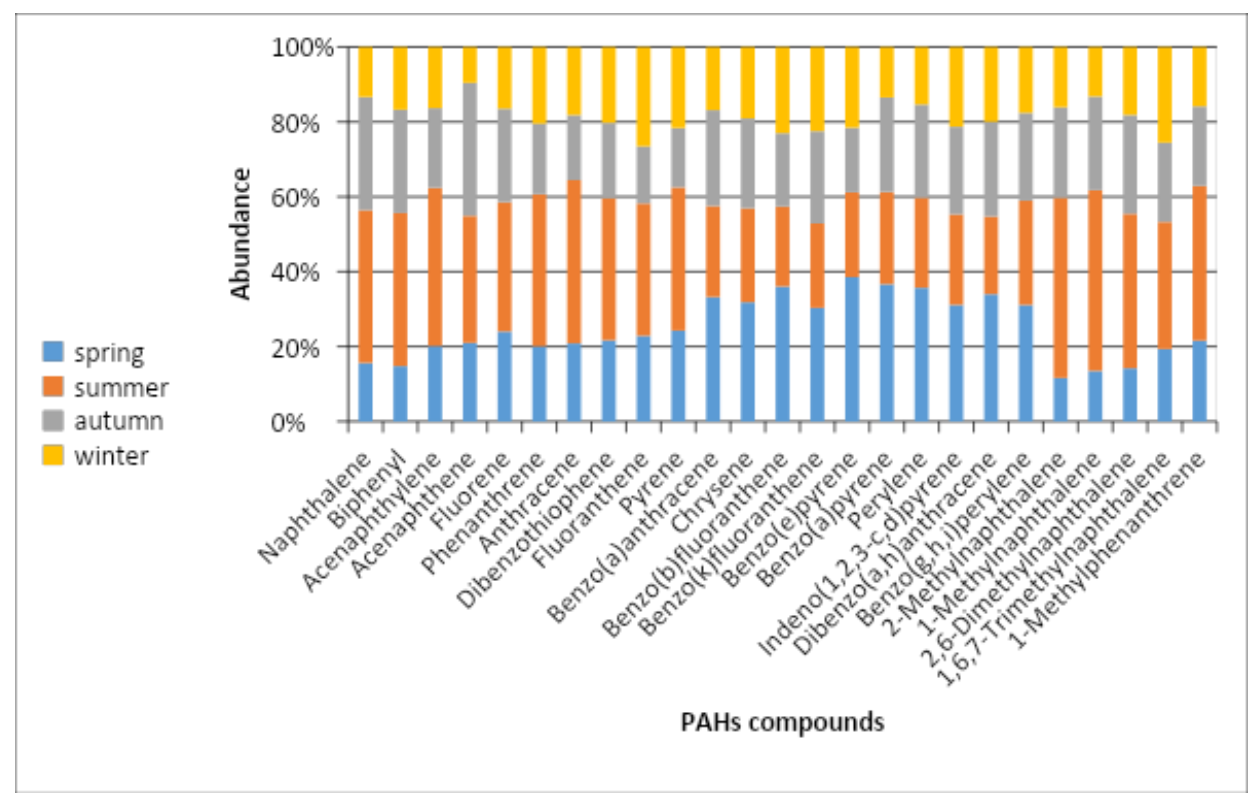

\section{PAHs source identification}

\section{(a) Diagnostic Ratios}

To assess the environmental and the human risks, it is significant to know the original source of PAHs. The highly utilized diagnostic tools to specify and characterize PAHs in ambient air is the ration values of individual PAHs congeners, though, sometimes, their results are unreliable (Kavouras et al., 2001; Yunker et al., 2002; Cincinelli et al., 2004, 2007; Katsoyiannis et al., 2011; Martellini et al., 2012; Katsoyiannis and Breivik, 2014). The ratio of IcdP/ (IcdP + BghiP) 
ranged between 0.25 and 0.45 in the particulate samples and as shown in the literature (Yunker et al., 2002), IcdP/ (IcdP + BghiP) ratios between 0.20 and 0.50 imply fuel combustion sources, such as vehicle and crude oil.

The obtained results of the current study indicate that the major sources of PAHs in the samples taken from the study areas come from fuel combustion processes and especially from vehicular traffic and non-traffic. BaP/BghiP ratios, which were remarkably higher than 0.1 clearly indicate that vehicles are the main source of PAHs, hence showing that traffic is the major source of this contaminants as they are released from fuel combustion (Fig. 3).

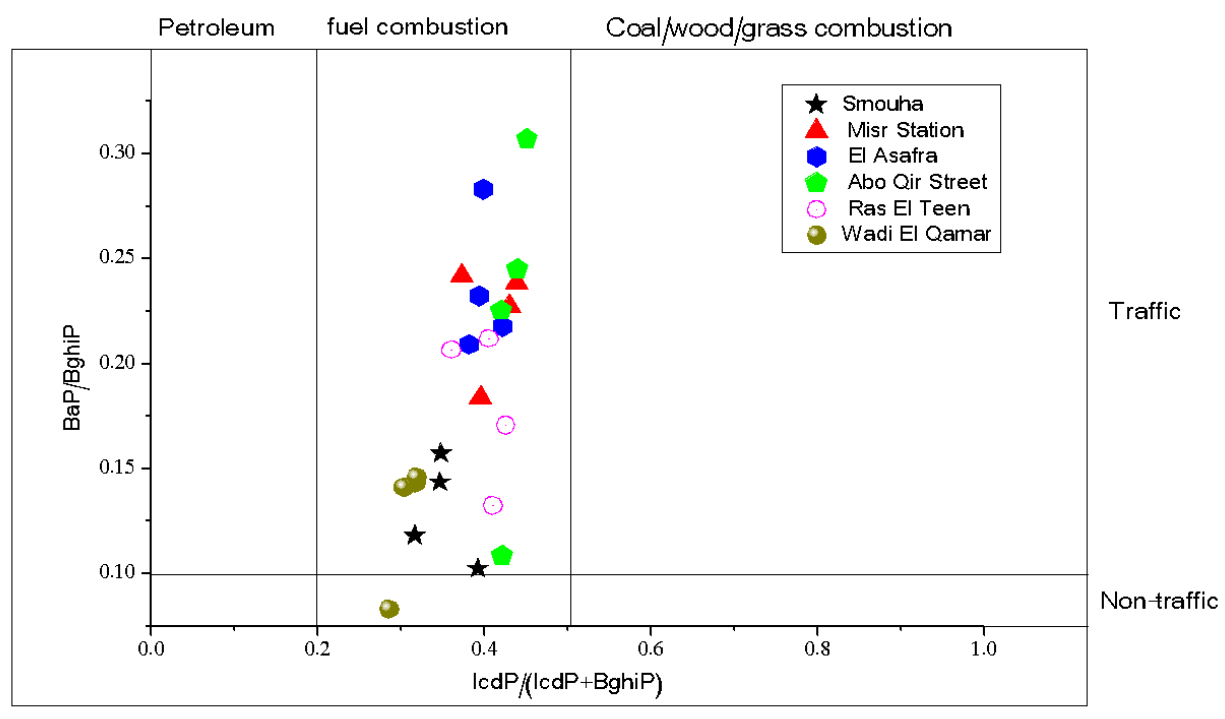

Fig. 3: Cross plot for the isomeric ratios of BaP/BghiP vs. IcdP/ (IcdP + BghiP) in Alexandria

Since the ratio of Ant/ $(\mathrm{Phe}+\mathrm{Ant})<0.1$ indicates that the main source is petroleum, and a ratio $>0.1$ indicates the dominance of combustión. the ratio of Ant/ (Phe + Ant), in the current study, was between 0.09 to 0.25 , thus indicating the dominance of combustion. In addition, a ratio of $\mathrm{Flu} /(\mathrm{Flu}+\mathrm{Pyr})<0.4$ stands for the petroleum input source, $0.4-0.5$ for petroleum combustion (especially liquid fossil fuel, vehicle and crude oil) (Yunker et al. 2002). The ratio of Flu/ (Flu + Pyr) ranged between 0.05 and 0.25 (Fig. 4), which reflects the major contribution of petroleum input. 
Vol. 5, No. 03; 2020

ISSN: $2456-8643$

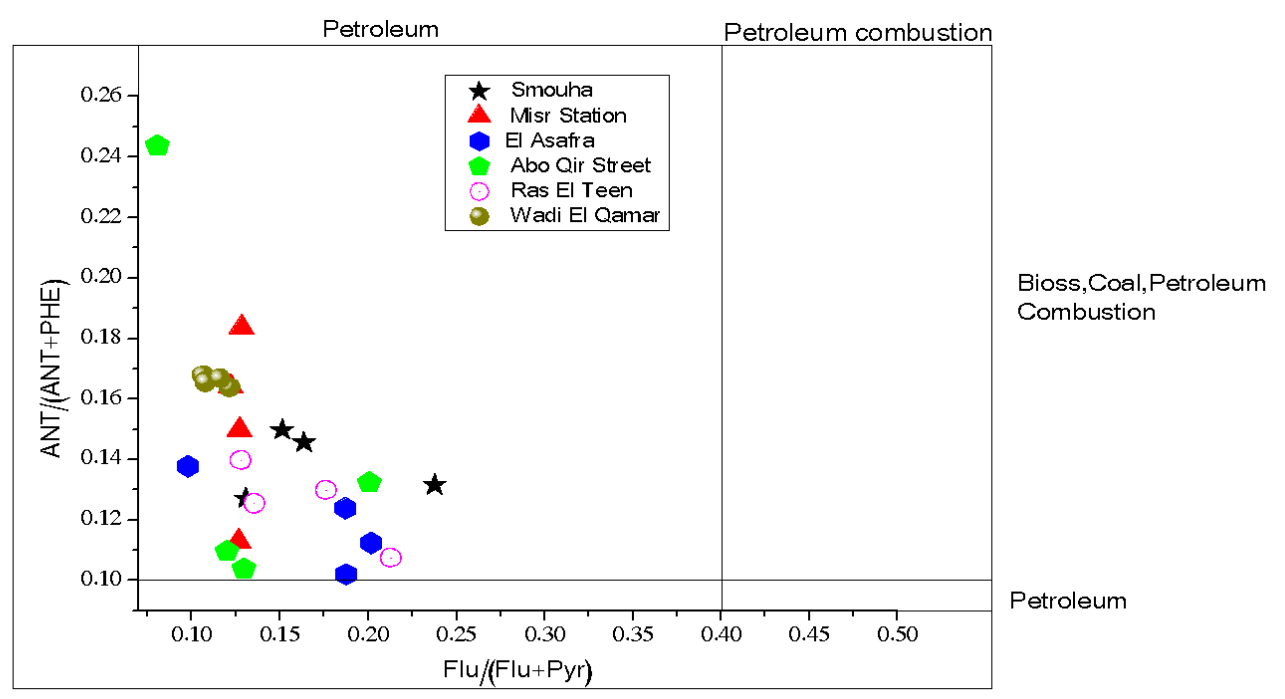

Fig. 4: Cross plot for the isomeric ratios of Ant/ (Phe + Ant) vs. Flu/ (Flu + Pyr) in Alexandria

(b) Factor analysis and multiple linear regression

According to Ravindra et al., 2006, FA/MLR is one of the significant methods to identify the main sources of emission air pollutants and to trace, based on statistics independent sources. In the current study, FA/MLR was applied to know the sources of PAHs emissions. Two PCs were used to collect data. PC 1 indicated $76 \%$ and PC 2 indicated 15\% (Fig. 5) of the total variance (91\%). PC 1 was mainly concerned with high weight molecular (HMW) PAHs, like indeno (123 $\mathrm{c}, \mathrm{d})$ pyrene, benzo(a)pyrene, benzo(g,h,i) perylene, perylene, dibenzo (ah) anthracene, benzo(k) fluoranthene, benzo(b) fluoranthene, benzo (a) anthracene and chrysene. This PAH resulting profile is in line with $\mathrm{PAH}$ emission profile released from vehicle emissions. Hence, indeno (123-c,d) pyrene, benzo (g,h,i) perylene, $\mathrm{BeP}, \mathrm{BaP}$ and benzo $(\mathrm{k})$ fluoranthene can be the tracers of vehicle exhaust (Sadiktsis et al., 2012). It is therefore suggested that PC 1 can be considered as a representative of pyrogenic sources, including vehicle emission. PC 2 is found in anthracene, phenanthracene, fluoranthene and DBT. It is also found that phenanthracene, fluoranthene and anthracene are highly predominant in combustion signals and therefore, it can be argued that the expected source of PAHs from FA/MLR is the mixed combustion. 


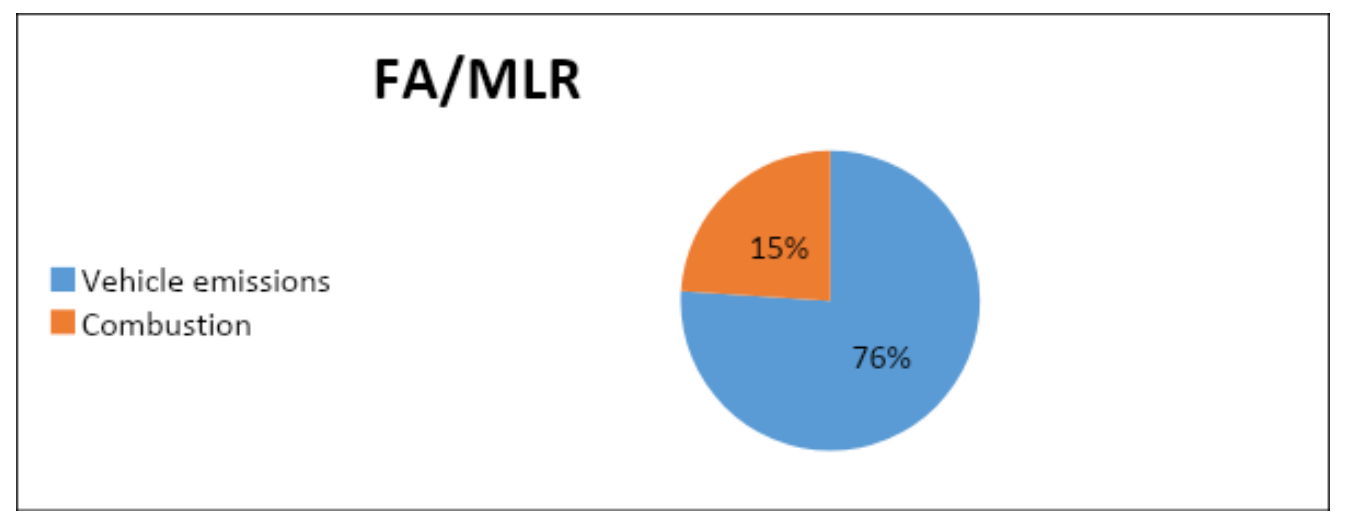

Fig. 5: Source contributions to the atmospheric PAH concentrations in Alexandria (FA/MLR)

(c) Positive matrix factorization

To measure the sources that contribute to PAHs, a dataset of 48 samples and $30 \mathrm{PAH}$ species was introduced into the EPA PMF 5.0 model. PAHs ambient concentrations in Alexandria throughout the four seasons were inputted as raw data to the PMF model. An uncertainty file for the present analysis was prepared and included the calculated Limit of Detection (LOD) as well as the recovery deviation of the surrogate standards (Larsen and Baker, 2003). The number varied for every dataset given the fact that the model was run several times every time from a different initial seed to fully understand the solution stability. Also, the model was run in the robust mode to prevent the outliers from affecting the results. The "optimal" solution (number of factors) was put into account to get a $\mathrm{Q}$ value that is approximate to the theoretical $\mathrm{Q}$ value and to avoid the solution dependence on the initial seed.

In each season, two source factors were extracted. Figure 6 shows the profiles that have resulted from PMF model. In the current study, factor 1 contributed 55.3\% of the total PAHs, which was similar to vehicle emissions. In vehicle emissions, the following substances were traced: indeno (123-c,d) pyrene, benzo (e) pyrene, benzo (g,h,i) perylene, perylene, dibenzo (ah) anthracene, benzo (k) fluoranthene, benzo (b) fluoranthene, and benzo (a) anthracene (Simcik et al. 1999; Lee et al. 2004; Ma et al. 2010). On the other hand, factor 2 contributed $44.6 \%$ of the total PAHs and the substances that were dominant in it were naphthalene, phenanthracene, flouranthene and DBT, which are also dominant in combustion signals. 


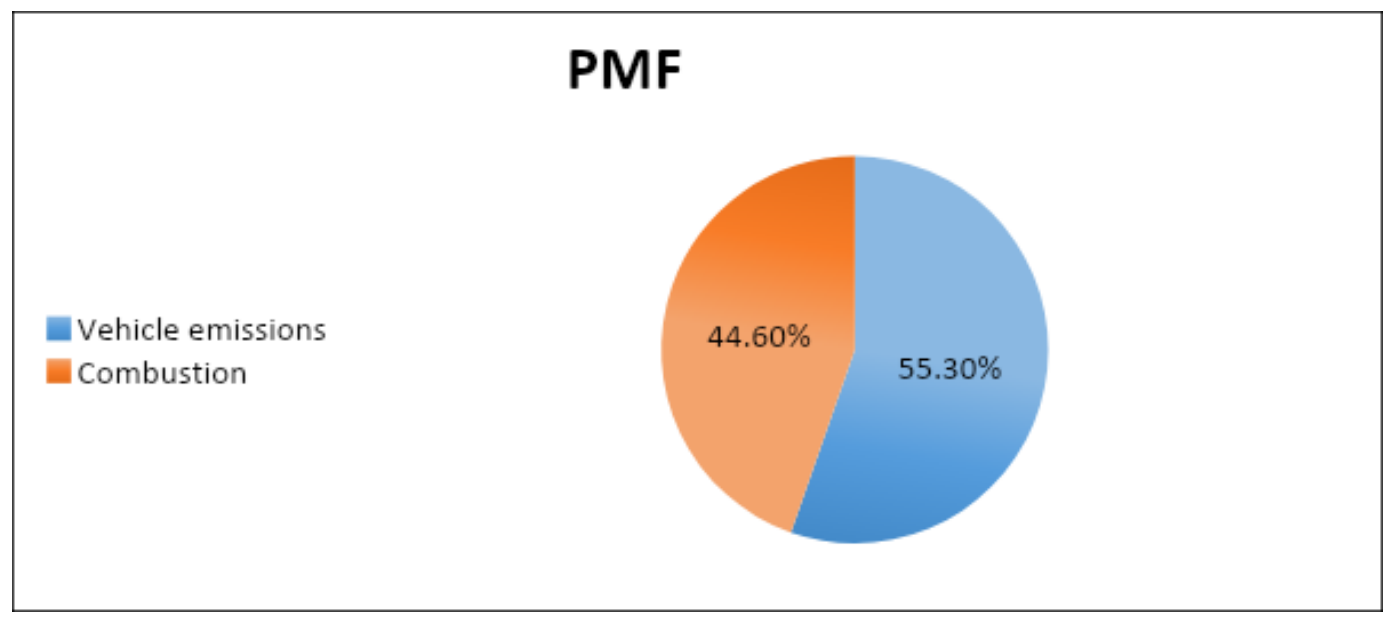

Fig. 6. Source contributions to the atmospheric PAH concentrations in Alexandria (PMF)

Cancer risk assessment from the exposure of atmospheric PAHs

(a) The questionnaire

Samples of 50 subjects randomly selected from the same sites according to a scheduled questionnaire were added to the atmospheric samples. This study adopted the descriptive crosssectional approach because it allows the researchers to investigate the spread of adverse health conditions among inhabitants and how they are related to PAHs concentration in the environment. The number of residents taken from different areas was 300 with age range between 18 and 60 years living in low to middle socio-economic standards. The significance and objectives of the study were explained before starting the interview with them and verbal consent was taken after assuring them of the confidentiality and security of the collected data. The researchers chose the major diseases related to PAHs such as asthma, bronchitis, liver diseases and lung cancer (Fig. 7). 


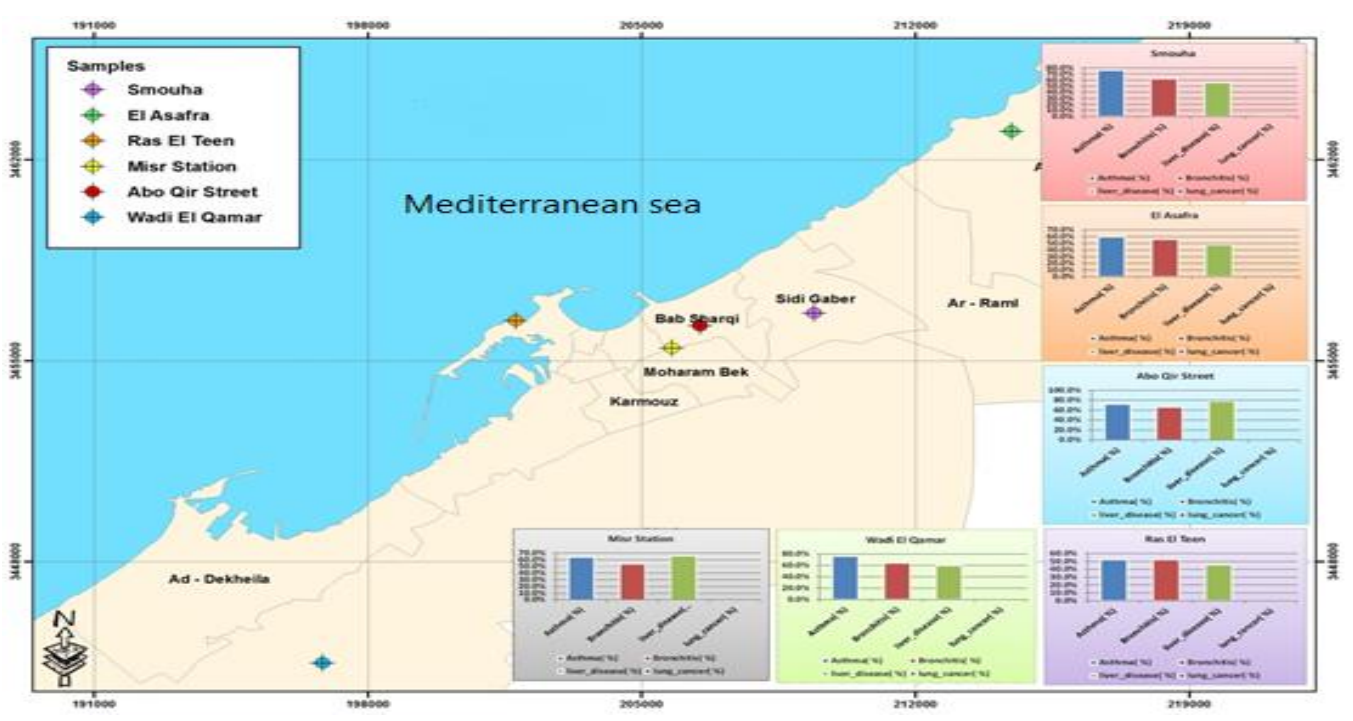

Fig. 7: Comparison between the results of questionnaire in the different sites

Wadi El-Qamar showed the highest percentage of people with asthma and bronchitis due to the fact that it is an industrial area that has a high traffic of heavy trucks. The area that has a similar percentage was Smouha that is a residential area, but has a lot of emissions from combustion of municipal wastes.

\section{(b) Risk assessment}

The main objective of the carried out risk assessment was to find out the potential of cancer development within the local residences of Alexandria due to exposures to atmospheric PAH concentrations through inhalation, ingestion or dermal exposure routes. To further support the risk assessment calculations, the geometric means of the four seasons for each of the 18 individual PAHs were added. Hence, the incremental lifetime cancer risks (ILTCR) for inhalation, ingestion and dermal exposure routes were calculated. Dermal (ILTCRder) contact to atmospheric PAHs $(1.49 * 10-6-0.154 * 10-3)$ revealed to have the higher potential of adverse health effects followed by the ingestion exposure route (ILTCRing) (7.02x10-7 -4.88 x10-5), and, finally the inhalation exposure route (ILTCRinh) $(3.24 \times 10-8-2.32 \times 10-6)$. The total incremental lifetime cancer risks (TILTCR) that were calculated ranged between $(2.25 \times 10-5$ and $1.54 \times 10-3)$.

Thus, it becomes evident that the calculated values for all the selected sites were higher than 105, which exceeds the USEPA accepted level of 10-6 (2004), leading to higher risk of carcinogenic diseases. It was proved that the main contributor to total lifetime cancer risk was the dermal contact exposure route that amounts to $>99 \%$ of the calculated values of TILTCR at all the sites under investigation. With regards to the target PAHs individual toxicity, some compounds constituted most of the estimated risk such as $\mathrm{BaP}(81.3-94.0 \%)$ and $\mathrm{BbF}$ (5.00-12.5 $\%)$ resulting from vehicular emissions. Therefore, the researcher came to the conclusion that the risk of cancer as a result of the emissions of PAHs from vehicles is of great import for future heath protection. 


\section{CONCLUSION}

Since Alexandria, Egypt is one of the major highly populated cities in Egypt that suffers from heavy traffic and numerous industrial plants, petroleum emissions play a significant role in PAH pollution. As a result, Alexandria atmospheric environment is obviously polluted by the PAHs concentrations more than any other urban city worldwide. Summer is revealed to be the season where the PAHs concentration reached the maximum due to congestion with tourists. As for the areas that had the highest PAH concentrations it was Wadi El-Qamar since it is the largest industrial zone in Alexandria. The results, based on PAH spatial distribution, temporal variations and sources allocations, indicated that emissions from vehicles and combustion are the utmost sources of PAHs in Alexandria. It has been concluded that thought both receptor models gave comparable results with consistency between the predicted and the measured PAH concentrations, the PMF model showed more reliability and accuracy than the FA/MLR model that results in a higher degree of uncertainty because calculations are based on the quality assurance data and the negative loadings constrains. The diagnostic ratios clearly illustrate that emissions from combustion and traffic are the major source of PAHs. Besides, dermal exposure followed by inhalation and ingestion are the most important exposure route for PAHs. Consequently, the potential of developing cancers becomes high due to exposure to PAHs through inhalation, ingestion and dermal contact.

\section{ACKNOWLEDGEMENT}

This study was supported by Geochemical and Environmental Research Group (GERG), Terry L. Wade, and Stephen T. Sweet (Texas A\&M University, USA) in the analysis of samples.

\section{CONFLICT OF INTEREST}

The author declares that there is no conflict of interests regarding the publication of this manuscript. In addition, the ethical issues, including plagiarism, informed consent, misconduct, data fabrication and/or falsification, double publication and/or submission, and redundancy have been completely observed by the authors. 
(NOMENCLATURE)

\begin{tabular}{|c|c|}
\hline$A B S$ & Adsorption Fraction \\
\hline$A F$ & Adherence Factor (milligram per cubic centimeter per hour) \\
\hline$A N$ & Acenaphthene \\
\hline ANL & Acenaphthylene \\
\hline Ant & Anthracene \\
\hline AT & the average life span (years) \\
\hline ATSDR & Agency for Toxic Substances and Disease Registry \\
\hline$B a A$ & Benzo (a) Anthracene \\
\hline$B a P$ & Benzo (a) pyrene \\
\hline$B b F$ & Benzo (b) fluoranthene \\
\hline $\mathrm{BeP}$ & Benzo (e) pyrene \\
\hline$B g P$ & Benzo $(g, h, i)$ perylene \\
\hline Bghip & Benzo $(g, h, i)$ perylene \\
\hline Biph & Biphenyl \\
\hline$B k F$ & Benzo (k) fluoranthene \\
\hline${ }^{\circ} \mathrm{C}$ & The degree Celsius \\
\hline CAMPAS & Central Agency for Public Mobilization and Statistics \\
\hline Chr & Chrysene \\
\hline CS & the total of the PAH levels \\
\hline DBahA & Dibenzo $(a, h)$ anthracene \\
\hline Diben & Dibenzothiophene \\
\hline$E$ & residual matrix \\
\hline$E D$ & Exposure Duration (years) \\
\hline EEAA & Egyptian Environmental Affairs Agency \\
\hline$E F$ & Exposure Frequency \\
\hline$F A / M L R$ & Factor Analysis/Multiple Linear Regression \\
\hline Fla & Fluoranthene \\
\hline Flu & Fluorene \\
\hline GC & Gas Chromatography \\
\hline GC/MS & Gas Chromatography/Mass spectrometry \\
\hline GC/MS/SIM & Gas Chromatography/Mass spectrometry/Selected-ion monitoring \\
\hline GERG & Geochemical and Environmental Research Group \\
\hline GFF & Glass Fiber Filter \\
\hline$H M W$ & High Molecular Weight Compounds \\
\hline km & kilometer \\
\hline ILCRs & Incremental Lifetime Cancer Risks \\
\hline IP & Indeno $(1,2,3,-c, d)$ pyrene \\
\hline IR Inhalation & Inhalation Rate (cubic meter per day) \\
\hline IR Ingestion & Intake Rate (milligram per day) \\
\hline$\angle O D$ & Limit of Detection \\
\hline$M D L$ & Method Detection Limit \\
\hline $\mathrm{m} / \mathrm{s}$ & Meter per second \\
\hline
\end{tabular}




\begin{tabular}{|ll|}
\hline Nap & Naphthalene \\
$n g / m^{3}$ & Nanogram per cubic meter \\
$p$ & number of factors involved \\
PAHs & Polycyclic Aromatic Hydrocarbons \\
$P C B s$ & Polychlorinated Biphenyls \\
$P E F$ & Particle Emission Factor (cubic meter per kilogram) \\
Per & Perylene \\
$P h e$ & Phenanthrene \\
$P M F$ & Positive Matrix Factorization \\
Pyr & Pyrene \\
QA/QC & Quality Assurance and Quality Control \\
$R P D$ & Relative Percent Difference \\
SA & dermal Surface Exposure (cubic centimeter) \\
SRM & Standard Reference Materials \\
$T E F$ & Toxic Equivalency Factor \\
$U$ & uncertainty \\
USEPA & United States Environmental Protection Agency \\
\hline
\end{tabular}

\section{REFERENCES}

Aboul-Kassim, T. A.; Simoneit, B. R., (1995). Aliphatic and Aromatic Hydrocarbons in Particulate Fallout of Alexandria, Egypt: Sources and Implications. Environ Sci Technol, 29(10):2473-83 (11 pages). https://pubmed.ncbi.nlm.nih.gov/22191944/

Albert, R.E.; Vanderlaan, M.; Burns, F.J.; Nishizumi, M., (1977). Effect of carcinogens on chicken atherosclerosis. Cancer Res, 37(7 Pt 1):2232-5 (4 pages).

https://pubmed.ncbi.nlm.nih.gov/405095/

ATSDR, (1995). Toxicological Profile for Polycyclic Aromatic Hydrocarbons (PAHs) Atlanta: Agency for Toxic Substances and Disease Registry.

https://www.atsdr.cdc.gov/toxprofiles/tp.asp?id=122\&tid=25

Barakat, A.O., (2002). PAHs and Petroleum Markers in the Atmospheric Environment of Alexandria City, Egypt. Water Air Soil Pollut, 139:289-310 (22 pages).https://link.springer.com/article/10.1023/A:1015894520672

Bartle, K., (1991). Analysis and occurrence of polycyclic aromatic hydrocarbons in food. In: Creaser C., Purchase, R., (Eds.). Food Contaminants: Sources and Surveillance (1st ed.). Woodhead Publishing.https://www.elsevier.com/books/food-contaminants/creaser/978-1-85573784-6 
Vol. 5, No. 03; 2020

ISSN: $2456-8643$

Baumard, P.; Budzinski, H.; Garrigues, P., (1998). Polycyclic aromatic hydrocarbons in sediments and mussels of the western Mediterranean sea. Environ Toxicol Chem, 17(5): 765-776 (12 pages).https://setac.onlinelibrary.wiley.com/doi/full/10.1002/etc.5620170501

CAMPAS, (2012). Annual Bulletin of Transportation Statistics. Cairo, Egypt.https://censusinfo.capmas.gov.eg/Metadata-ar-v4.2/index.php/catalog/156

Chen, S; Liao, C., (2006). Health risk assessment on human exposed to environmental polycyclic aromatic hydrocarbons pollution sources. Sci Total Environ, 366(1):112-123 (12 pages).https://www.sciencedirect.com/science/article/abs/pii/S0048969705005693

Cincinelli, A.; Stefani, A.; Costantini, S. S.; Lepri, L., (2004). Characterization of N-Alkanes and

PAHs in PM10 Samples in Prato (Italy). Ann Chim, 94(4):281-93 (13 pages).https://pubmed.ncbi.nlm.nih.gov/15242093/

Cincinelli, A.; Bubba, M. D.; Martellini, T.; Gambaro, A.; Lepri, L., (2007). Gas-particle Concentration and Distribution of N-Alkanes and Polycyclic Aromatic Hydrocarbons in the Atmosphere of Prato (Italy). Chemosphere, 68(3):472-8 (7 pages).

https://pubmed.ncbi.nlm.nih.gov/17307224/

Curfs, D. M.; Knaapen, A. M.; Pachen, D. M.; Gijbels, M.J.; Lutgens, E.; Smook, M.L.; Kockx, M.M.; Daemen, M.J.; van Schooten, F.J., (2005). Polycyclic aromatic hydrocarbons induce an inflammatory atherosclerotic plaque phenotype irrespective of their DNA binding properties. FASEB J, 19(10):1290-2 (3 pages).https://pubmed.ncbi.nlm.nih.gov/15939734/

EEAA, (2007). Environmental Characterization of Alexandria, Egypt. Egyptian Environmental Affairs Agency.www.eeaa.gov.eg/english/reports/GovProfiles/final/Alex\%20Des.pdf

Esen, F.; Cindoruk, S. S.; Tasdemir, Y., (2008). Bulk Deposition of Polycyclic Aromatic Hydrocarbons (PAHs) in an Industrial Site of Turkey. Environ Pollut, 152(2):461-7 (7 pages).https://pubmed.ncbi.nlm.nih.gov/17683835/

Gaga, E. O.; Ari, A.; Döğeroğlu, T.; Çakırca, E. E.; Machin, N. E., (2012). Atmospheric Polycyclic Aromatic Hydrocarbons in an Industrialized City, Kocaeli, Turkey: Study of Seasonal Variations, Influence of Meteorological Parameters and Health Risk Estimation. J Environ Monit, 14(8):2219-29 (11 pages).https://pubmed.ncbi.nlm.nih.gov/22699796/

Galarneau, E., (2008). Source specificity and atmospheric processing of airborne PAHs: Implications for source apportionment. Atmos. Environ., 42(35): 8139-8149 (11 pages).https://www.sciencedirect.com/science/article/abs/pii/S1352231008006602

Gregoris, E.; Argiriadis, E.; Vecchiato, M.; Zambona, S.; De Pieri, S.; Donateo, A.; Contini, D.; Piazza, R.; Barbante, C.; Gambaro, A., (2014). Gas-particle distributions, sources and health effects of polycyclic aromatic hydrocarbons (PAHs), polychlorinated biphenyls (PCBs) and polychlorinated naphthalenes (PCNs) in Venice aerosols. Sci Total Environ, 476-477:393-405 (13 pages).https://www.sciencedirect.com/science/article/abs/pii/S004896971400045X 
Hassan, S. K.; Khoder, M. I., (2012). Gas-particle Concentration, Distribution, and Health Risk Assessment of Polycyclic Aromatic Hydrocarbons at a Traffic Area of Giza, Egypt. Environ Monit Assess, 184(6):3593-612 (20 pages).https://pubmed.ncbi.nlm.nih.gov/21789535/

Jang, E.; Alam, M. S.; Harrison, R. M., (2013). Source apportionment of polycyclic aromatic hydrocarbons in urban air using positive matrix factorization and spatial distribution analysis. Atmos Environ, 79: 271-285 pages).https://www.sciencedirect.com/science/article/pii/S1352231013005219

Katsoyiannis, A.; Terzi E.; Cai, Y., (2007). On the use of PAH molecular diagnostic ratios in sewage sludge for the understanding of the PAH sources. Is this use appropriate? Chemosphere, 69(8):1337-1339 (3 pagehttps://www.sciencedirect.com/science/article/pii/S0045653507007461

Katsoyiannis, A.; Sweetman, A.; Jones, K., (2011). PAH molecular diagnostic ratios applied to atmospheric sources: a critical evaluation using two Decades of source Inventory and air concentration data from the UK. Environ Sci Technol, 45(20): 8897-8906 (10 pages).https://www.ncbi.nlm.nih.gov/pubmed/21859122

Katsoyiannis, A; Breivik, K., (2014). Model-based evaluation of the use of polycyclic aromatic hydrocarbons molecular diagnostic ratios as a source identification tool. Environ Pollut, 184:488-494 (7 pages).https://www.sciencedirect.com/science/article/pii/S0269749113005022

Kavouras, I. G.; Koutrakis, P.; Tsapakis, M.; Lagoudaki, E.; Stephanou, E. G.; Baer, D. V.; Oyola, P., (2001). Source Apportionment of Urban Particulate Aliphatic and Polynuclear Aromatic Hydrocarbons (PAHs) Using Multivariate Methods. Environ. Sci. Technol., 35(11):2288-2294 (7 pages).https://pubs.acs.org/doi/10.1021/es001540z

Kennish, M. J., (1992). Ecology of Estuaries: Anthropogenic Effects. Boca Raton, FL: CRC Press.https://books.google.com.eg/books?id=F_W9DwAAQBAJ\&printsec=frontcover\&dq=Ecol ogy+of+Estuaries:+Anthropogenic+Effects\&hl=ar\&sa=X\&ved=0ahUKEwixgeroptTpAhVC5uA KHScvBgYQ6AEIJzAA

Khairy, M.; Lohmann, R., (2013). Source apportionment and risk assessment of polycyclic aromatic hydrocarbons in the atmospheric environment of Alexandria, Egypt. Chemosphere, 91(7):895-903 (9 pages).https://www.sciencedirect.com/science/article/pii/S0045653513003081

Krauss, M.; Wilcke, W.; Martius, C.; Bandeira, A. G.; Garcia, M. V. B.; Amelung, W., (2005). Atmospheric Versus Biological Sources of Polycyclic Aromatic Hydrocarbons (PAHs) in a Tropical Rain Forest Environment. Environ Pollut, 135(1):143-54 (12 pages).https://pubmed.ncbi.nlm.nih.gov/15701401/

Larsen, R.; Baker, J., (2003). Source apportionment of polycyclic aromatic hydrocarbons in the urban atmosphere: a comparison of three methods. Environ Sci Technol, 37(9):1873-1881 (9 pages).https://pubs.acs.org/doi/10.1021/es0206184 
Vol. 5, No. 03; 2020

ISSN: $2456-8643$

Lee, J.H.; Gigliotti, C.L.; Offenberg, J.H.; Eisenreich, S.J.; Turpin, B.J., (2004). Sources of polycyclic aromatic hydrocarbons to the Hudson River Airshed. Atmos Environ, 38(35):59715981 (11 pages).https://www.sciencedirect.com/science/article/abs/pii/S1352231004006867

Lestari, P.; Mauliadi, Y. D. (2009). Source apportionment of particulate matter at urban mixed site in Indonesia using PMF. Atmos Env, 43 (10):1760-1770 pages).https://www.sciencedirect.com/science/article/abs/pii/S1352231008011485

Li, J.; Zhang, G.; Li, X. D.; Qi, S. H., Liu, G. Q.; Peng, X. Z., (2006). Source Seasonality of Polycyclic Aromatic Hydrocarbons (PAHs) in a Subtropical City, Guangzhou, South China. Sci Total Environ, 355(1-3):145-55 (11 pages).https://pubmed.ncbi.nlm.nih.gov/16137742/

Ma, W.; Li, Y.; Qi, H.; Sun, D.; Liu, L.; Wang, D., (2010). Seasonal Variations of Sources of Polycyclic Aromatic Hydrocarbons (PAHs) to a Northeastern Urban City, China. Chemosphere, 79(4):441-7 (7 pages).https://pubmed.ncbi.nlm.nih.gov/20167349/

Martellini, T.; Giannoni, M.; Lepri, L.; Katsoyiannis, A.; Cincinelli, A., (2012). One Year Intensive PM2.5 Bound Polycyclic Aromatic Hydrocarbons Monitoring in the Area of Tuscany, Italy. Concentrations, Source Understanding and Implications. Environ Pollut, 164:252-8 (7 pages). https://pubmed.ncbi.nlm.nih.gov/22377904/

Yunker, M. B.; Macdonald, R. W.; Vingarzan, R.; Mitchell, R. H.; Goyettee, D.; Sylvestrec, S., (2002). PAHs in the Fraser river basin: a critical appraisal of PAH ratios as indicators of PAH source and composition. Org Geochem, 33:489-515 (28 pages).https://www.sciencedirect.com/science/article/abs/pii/S0146638002000025

Nassar, H.; Tang, N.; Kameda, T.; Toriba, A.; Khoder, M.; Hayakawa, K., (2011). Atmospheric concentrations of polycyclic aromatic hydrocarbons and selected nitrated derivatives in Greater Cairo, Egypt. Atmos Environ, 45(39):7352-7359 (8 pages).

https://www.sciencedirect.com/science/article/abs/pii/S1352231011007874

Oliva, M.; González de Canales, M. L.; Gravato, C.; Guilhermino, L.; Perales, J. A.; (2010). Biochemical Effects and Polycyclic Aromatic Hydrocarbons (PAHs) in Senegal Sole (Solea Senegalensis) From a Huelva Estuary (SW Spain). Ecotoxicol Environ Saf, 73(8):1842-51 (10 pages).https://pubmed.ncbi.nlm.nih.gov/20843549/Paatero, P.; Tapper, U., (1994). Positive matrix factorization: A non-negative factor model with optimal utilization of error estimates of data values. Environmetrics, 5(2): 111-126 (16 pages).

https://onlinelibrary.wiley.com/doi/abs/10.1002/env.3170050203Park, S. S.; Kim, Y. J.; Kang, C. H., (2002). Atmospheric polycyclic aromatic hydrocarbons in Seoul, Korea. Atmos Environ, 36(17): 2917-2924 (8 pages).

https://www.sciencedirect.com/science/article/abs/pii/S1352231002002066 
Peng, C.; Chen, W.; Liao, X.; Wang, M.; Ouyang, Z.; Jiao, W.; Bai, Y., (2011). Polycyclic aromatic hydrocarbons in urban soils of Beijing: Status, sources, distribution and potential risk. Environ Pollut, 159(3):802-808 (7 pages).

https://www.sciencedirect.com/science/article/pii/S0269749110005117

Penn, A.; Snyder, C., (1988). Arteriosclerotic plaque development is 'promoted' by polynuclear aromatic hydrocarbons. Carcinogenesis, 9(12):2185-9 (5 pages).

https://pubmed.ncbi.nlm.nih.gov/3142695/

Ravindra, K.; Bencsa, B.; Eric W.; Johan de, H.; Felix D.; Edward, R.; Nico, B.; Patrick, B.; Rene' Van, G., (2006). Seasonal and site-specific variation in vapour and aerosol phase PAHs over Flanders (Belgium) and their relation with anthropogenic activities. Atmos Environ, 40(4):771-785 (15 pages).

https://www.sciencedirect.com/science/article/abs/pii/S1352231005009775

Sadiktsis, I; Bergvall, C.; Johansson, C.; Westerholm, R., (2012). Automobiletires-a potential source of highly carcinogenic dibenzopyrenes to the environment. Environ Sci Technol, 46(6):3326-3334 (9 pages).https://pubs.acs.org/doi/abs/10.1021/es204257d

Simcik, M.; Eisenreich, S.; Lioy, P., (1999). Source apportionment and source/sink relationships of PAHs in the coastal atmosphere of Chicago and Lake Michigan. Atmos Environ, 33(30):50715079 (9 pages).https://www.sciencedirect.com/science/article/abs/pii/S1352231099002332

Slezakova, K.; Castro, D.; Begonha, A.; Delerue-Matos, C.; Alvim-Ferraz, M. C.; Morais, S.; Pereira, M. C., (2012). Evaluation of atmospheric deposition and patterns of polycyclic aromatic hydrocarbons in façades of historic monuments of Oporto (Portugal). International Journal of Environmental Analytical Chemistry, 93:1052-1064 (13 pages).

https://www.tandfonline.com/doi/abs/10.1080/03067319.2013.775279

Tauler, R.; Viana, M.; Querol, X.; Alastuey, A.; Flight, R.; Wentzell, P.D.; Hopke, P., (2009). Comparison of the results obtained by four receptor modelling methods in aerosol source

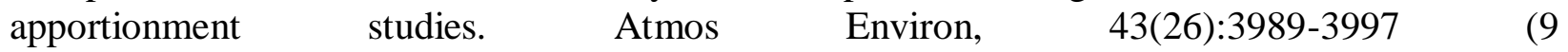
pages).https://www.sciencedirect.com/science/article/abs/pii/S1352231009004464

Tobiszewski, M.; Namieśnik, J., (2012). PAH diagnostic ratios for the identification of pollution emission sources. Environ Poll, 162:110-119 pages).https://www.sciencedirect.com/science/article/pii/S0269749111006051

US Department of Health and Human Services, (2019). 2019 Annual Report - National Toxic https://ntp.niehs.nih.gov/annualreport/2019/annualreport_508.pdf

US EPA, (1991). Risk Assessment Guidance for Superfund, Volume 1, Human health evaluation manual (Part B, Development of risk-based preliminary remediation goals). OSWER, [9285.7- 
01B.EPA/540/R-92/003].https://www.epa.gov/risk/risk-assessment-guidance-superfund-ragspart-b

US EPA, (2008). Polycyclic aromatic hydrocarbons (PAHs) - EPA fact sheet. Washington (DC): National Center for Environmental Assessment, Office of Research and Development.

https://archive.epa.gov/epawaste/hazard/wastemin/web/pdf/pahs.pdf

Vasilakos, C; Levia, N.; Maggosa, Th.; Hatzianestis, J.; Michopoulos, J.; Helmis, C., (2006). Gas-particle concentration and characterization of sources of PAHs in the atmosphere of a suburban area in Athens, Greece. J Hazard Mater, 140(1-2):45-51 (7 pages).

https://www.sciencedirect.com/science/article/abs/pii/S0304389406006868

Wade, T. L.; Atlas, E. L.; Brooks, T. L.; Kennicutt, M. C.; Fox, R. G.; Sericano, J.; GarciaRoero, B.; Defreitas, D. A., (1988). NOAA gulf of Mexico status and trends program: Trace organic contaminant distribution in sediments and oysters. Estuaries, 11:1171-1179 (9 pages).

https://link.springer.com/article/10.2307/1351969

Wang, W.; Simonich, S.; Giri, B.; Chang, Y.; Zhang, Y.; Jia, Y.; Tao, S.; Wang, R.; Wang, B.; Li, W.; Cao, J.; Lua, X., (2011). Atmospheric concentrations and air-soil gas exchange of polycyclic aromatic hydrocarbons (PAHs) in remote, rural village and urban areas of BeijingTianjin region, North China. Sci Total Environ, 409(15): 2942-2950 (9 pages).

https://www.ncbi.nlm.nih.gov/pmc/articles/PMC3718390/

Wang, Z.; Ren, P.; Sun, Y.; Ma, X.; Liu, X.; Na, G.; Yao, Z, (2013). Gas/particle partitioning of polycyclic aromatic hydrocarbons in coastal atmosphere of the north Yellow Sea, China. Environ Sci Pollut Res Int, 20(8):5753-63 (11 pages).

https://www.ncbi.nlm.nih.gov/pubmed/23463281

Yunker, M.; Macdonald, R.; Vingarzan, R.; Mitchell, R.; Goyette, D.; Sylvestre, S., (2002). PAHs in the Fraser River Basin: a critical appraisal of PAH ratios as indicators of PAH source and composition. Org Geochem, 33(4):489-515 (27 pages).https://www.sciencedirect.com/science/article/abs/pii/S0146638002000025Zhang, Y.; Guo, C.; Xu, J.; Tian, Y.; Shi, G.; Feng, Y., (2012). Potential source contributions and risk assessment of PAHs in sediments from Taihu Lake, China: Comparison of three receptor models. Water $\quad$ Res., 46(9):3065-3073 pages).https://www.sciencedirect.com/science/article/abs/pii/S0043135412001698 


\section{GRAPHICAL ABSTRACT}

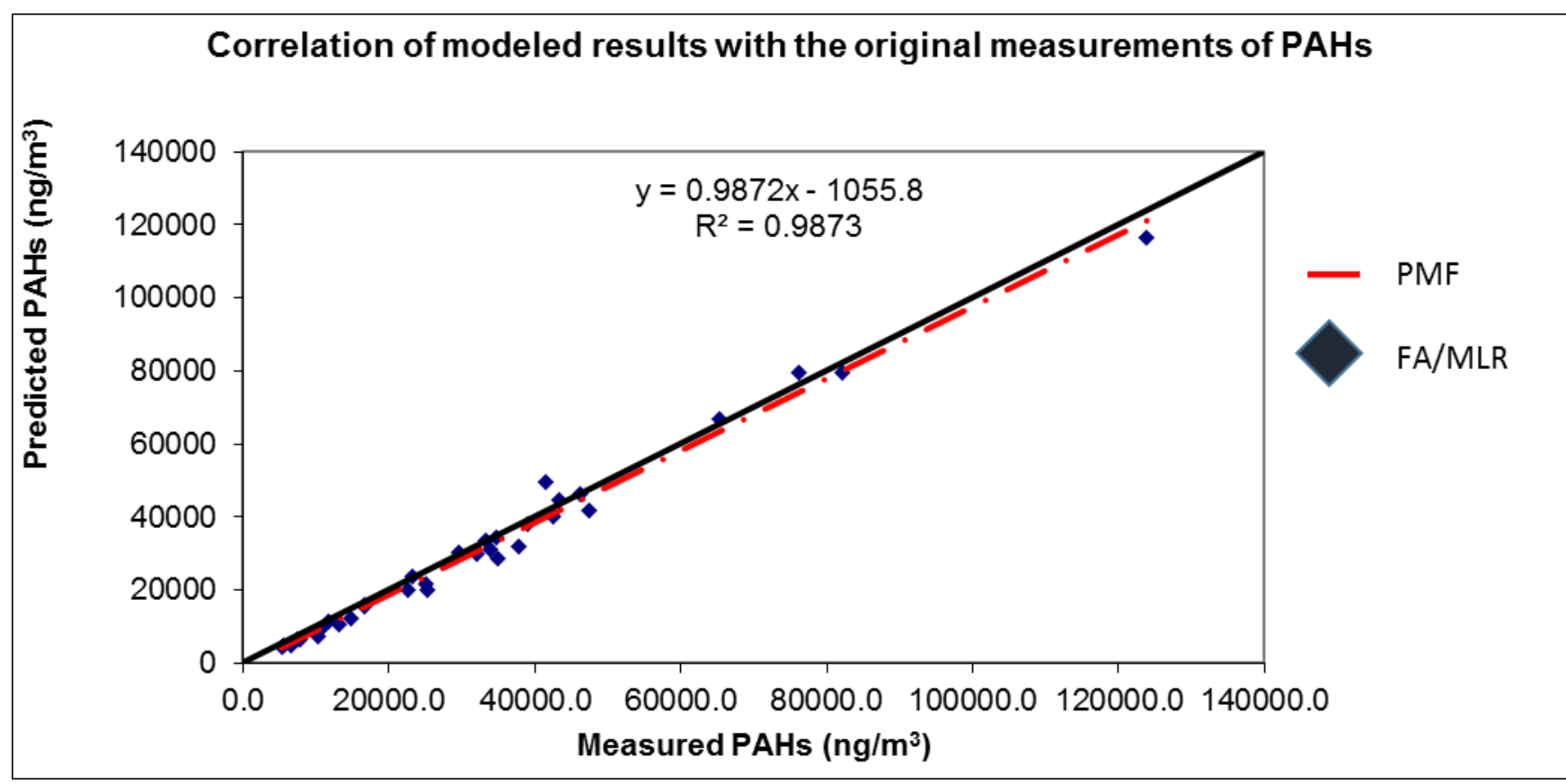

\section{HIGHLIGHTS}

Atmospheric environment of Alexandria, Egypt is highly polluted with PAHs, with concentrations much higher than in other urban cities worldwide.

$>$ The spatial distribution of PAHs, temporal variations and source apportionment results indicated that vehicle emissions and combustion are the major sources of PAHs in Alexandria.

$>$ PMF model are more reliable and accurate than the FA/MLR model which is associated with a higher degree of uncertainty because of the independence of the calculations on the quality assurance data and the negative loadings constrains.

$>$ The most important exposure route for PAHs would appear to be via dermal exposure followed by inhalation and ingestion. 